\title{
The importance of the Dead Sea Scrolls for the study of the explicit quotations in Ad Hebraeos
}

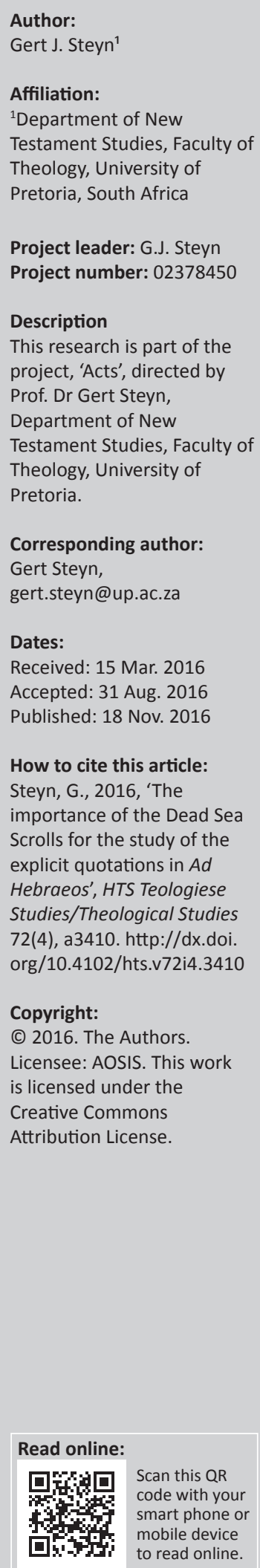

The important contribution that the Dead Sea Scrolls (DSS) hold for New Testament studies is probably most evident in Ad Hebraeos. This contribution seeks to present an overview of relevant extant DSS fragments available for an investigation of the Old Testament explicit quotations and motifs in the book of Hebrews. A large number of the explicit quotations in Hebrews were already alluded to, or even quoted, in some of the DSS. The DSS are of great importance for the study of the explicit quotations in Ad Hebraeos in at least four areas, namely in terms of its text-critical value, the hermeneutical methods employed in both the DSS and Hebrews, theological themes and motifs that surface in both works, and the socio-religious background in which these quotations are embedded. After these four areas are briefly explored, this contribution concludes, among others, that one can cautiously imagine a similar Jewish sectarian matrix from which certain Christian converts might have come - such as the author of Hebrews himself.

\section{Introduction}

The relation between the text readings found among the Dead Sea Scrolls (DSS), those of the LXX witnesses and the quotations in Ad Hebraeos ${ }^{1}$ needs much more attention (Batdorf 1972:16-35; Bruce 1962/1963:217-232; Grässer 1964:171-176; Steyn 2003a:493-514; Wilcox 1988:647-656). ${ }^{2}$ How does one explain, for instance, the fact that the subject matter of Hebrews 1:1-5 agrees closely with that of 4QFlor, ${ }^{3}$ that three of the seven texts quoted there overlap with Ad Hebraeos (2 Sm 7:10-14; Is 8:11; Ps 2:7) and that Psalm 45:1-2 is also quoted in the DSS? However, apart from the Psalter, what does one do with the striking prominence of the Melchizedek motif shared in 11QMelch and Ad Hebraeos? Although one might differ on the detail of some similarities as briefly pointed out in the past, the special affinity to the DSS that is shown by Ad Hebraeos should be noted (Attridge 1989:28-29; Bruce 1985:li; Weiss 1991:381). ${ }^{4}$ Added to this is the fact that the Hebrew equivalents of the introductory formulae in the New Testament (NT) are found in greater abundance in the Qumran literature than among all the known early rabbinic literature (such as the Mishnah) (Fitzmyer 1968:253; Metzger 1951:297-307; Terry 1975:504). ${ }^{5}$

The DSS are of great importance for the study of the explicit quotations in Ad Hebraeos in at least four areas, namely their text-critical value, the hermeneutical methods employed, theological themes and motifs that surface, and the socio-religious background in which they are embedded. ${ }^{6}$

\section{Text-critical importance}

The role of the DSS in the reconstruction of the LXX Vorlage has become vividly clear in LXX studies in recent years. Therefore, the resemblances between the text readings of the DSS and the Vorlage of 'the' LXX7 - with its similarities in Ad Hebraeos - ought to be taken seriously into account 1.In order to avoid reference to the Letter [sic] to the Hebrews, as well as confusion between the NT book of Hebrews and the Hebrew language, I employ the term Ad Hebraeos.

2.1 repeat here the same questions I raised earlier in my investigation of the quotation from Psalms 8 in Hebrews 2.

3.It also agrees with that of Hebrews 1:5-13, according to Bateman (1995:11-27).

4.'The fact that next to Acts the Epistle to the Hebrews shows so much affinity to the DSS proves once again, from a different angle, the strong connection between these two New Testament writings' (De Waard 1965:81-82).

5.For a comparison between NT and rabbinical formulas.

6.This contribution is a revised and edited composition of selected aspects related to the role of the Dead Sea Scrolls during a recent quest to establish the assumed LXX Vorlage of the explicit quotations in Hebrews (cf. Steyn 2011b).

7.Fernández Marcos (2000) is correct in saying:

It is difficult to overestimate the impact made by the finds from the Desert of Judah on the understanding of the history of the biblical text and more particularly on the early history of the LXX and its relationship to the Hebrew text. (p. 70) 
in an investigation on the quotations in Ad Hebraeos. ${ }^{8}$ Commentaries in general, and German scholarship in particular, have worked with this as a basic assumption for explaining a number of differences in the readings of the quotations in Ad Hebraeos. Examples include the studies of De Waard (1965), Ahlborn (1966), Schröger (1968), Karrer (2002, 2008) and Rüsen-Weinhold (2004). These are mainly studies that pay attention to the text-critical value of the DSS, not only for the reconstruction of the LXX versions but also for studies on the text form of the NT quotations.

\section{Corpus of textual witnesses available attesting to the Old Testament text quoted}

The readings of some of the quoted texts in Ad Hebraeos are in closer agreement with existing DSS witnesses, against the readings of the Masoretic Text (MT) and the LXX. As there is no direct connection between the DSS and Ad Hebraeos, it raises the possibility of these readings being remnants of an earlier Hebrew form of the LXX (cf. Cook 1992:107-130; Tov 1992:11-47; Ulrich 1992:49-80). In addition, the oldest LXX papyri at Qumran testify to a Greek text that seems to be closer to that found in the MT. The quotation in Heb 1:6 from Dt 32:43 is a case in point (Karrer 2006:349-353; McLay 2003:107-114, 2006:51-55; Steyn 2000:263-272). The quoted line does not appear in the MT (which only consists of four stichoi) but is found in 4QDeut (consisting of eight stichoi) - probably representing a similar Hebrew text from which the LXX translations of Dt 32:43 and Ode 2 in Codex A were made.

\section{Quotations in Ad Hebraeos with attestation in the Dead Sea Scrolls}

Four of the quoted texts in Ad Hebraeos have also been quoted in the DSS, although from a different verse in the same passage. These include the quotations from Psalm 2:7 in Hebrews 1:5 and 5:5; Isaiah 8:17-18 in Hebrews 2:13; Psalm 45:7 in Hebrews 1:8; and Psalm 118:6 in Hebrews 13:6.

- Psalm 2:7 (4Q174 = Ps 2:1): Verses 1-2 are quoted in 4QFlor (4Q174) 1:18-19. It is the last in a list of seven quotations preserved on the DSS fragment and is expanded upon with an added midrash (Steyn 2003b:262282). Among the DSS, there are two fragments that contain the text of Psalm 2:7, namely 11QPsc (= 11Q7, containing Ps 2:6-7) and 3QPs (=3Q2, containing Ps 2:1$8)$. The readings are in exact agreement with our known Hebrew readings from the MT (Washburn 2002:86).

- Isaiah 8:17-18 (4Q174 = Is 8:11): The most important witness among the DSS with regard to the Hebrew versions of Isaiah 8:17-18 for this study is the great Isaiah Scroll (1QIs ${ }^{\mathrm{a}}-$ column VIII, lines 10-11) (Høgenhaven 1998:151-158). ${ }^{9}$ A comparison between the texts of Isaiah $8: 17 \mathrm{~b}-18$ in 1QIs ${ }^{\mathrm{a}}$ and the MT shows only the following two variations: (1) v. 18 , which begins about in the middle of line 10 in $1 \mathrm{QIs}^{\mathrm{a}}$,

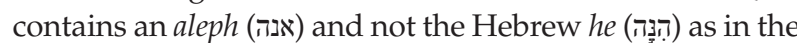
MT, and (2) the next word reads (without a waw) in the

\footnotetext{
8.See Steyn (2011b) for a comprehensive investigation on the possible Vorlage(n) of the quotations in Hebrews. The supporting role of the DSS in the reconstruction of the quor LX versions contributes to the value of identifying trajectories of th different ancient LXX versions during New Testament times.
}

9.For a brief overview of the state of affairs and important literature.
MT but אנוכי (with a waw) in 1QIsa. Whilst the latter is merely an alternative form of writing (Cook 1989:291-303, 1994:133-147), ${ }^{10}$ the former represents the difference between the attention marker 'Look!' (MT) and the Qal 'lament' $\left(1 \mathrm{QIs}{ }^{\mathrm{a}}\right)$. The LXX Greek translations in this instance are following a Hebrew text that is closer to the MT when translating i iovó. Since the work of the LXX scholars Ziegler ${ }^{11}$ and Seeligmann, it is widely known that the LXX Isaiah ${ }^{12}$ represents a much more free translation, which contains often striking differences at a number of places for syntactical, exegetical or interpretative reasons (Van der Kooij 1997:11). Even before the DSS discoveries, it was observed that the Vorlage of the LXX Isaiah was most probably not a Greek transcribed text but a Hebrew consonant text, of which the alphabet was a new Aramaic one with a tendency to square script - as is the case in the Pentateuch, although the tendency in the Isaiah Vorlage to square script seemed to be stronger (Fischer 1930:89). The importance of the DSS for the understanding of the LXX Vorlage was further emphasised by acknowledging that in the quest for the Hebraic Vorlage of the LXX Isaiah, the DSS witnesses (especially Qa) are equally important alongside those of the MT (Van der Kooij 1997:11). Then again in other cases, such as in a comparison of the contents of LXX Isaiah 8:11-16 with those of MT Isaiah 8:11-18, it became clear that the Greek text differed substantially from both the MT and 1QIs ${ }^{\mathrm{a}}$ in terms of its contents..$^{13}$ The conclusion of Van der Kooij (1989:127-133, 1989/1990:569-581) is that each of the passages (LXX Is 8:11-16 and 1QIs $8: 11-18)^{\prime}$ '... constitutes a coherent text in its own right, containing a form and content quite different from the other, and each one is different from MT as well. Deviations or variant readings turned out to be part of a particular interpretation' (Van der Kooij 1992:205).

- Psalm 45:7 (4Q171 = Ps 45:1-2) ${ }^{14}$ : In the Old Testament (OT), the element of the 'sceptre' surfaces as a symbol for the king - a motif that is found again in the DSS when Numbers 24:13 is quoted in CD 7:19b-20. In this passage the sceptre is interpreted as the prince of the whole congregation'. The motif also surfaces in Ps. Sol. 17:24 (Braun 1966:243) when 'an iron rod' will be used by the son of David during his rule over Israel (v. 21). Furthermore, it should be noted that among the pesharim of the DSS, a combination of Psalm 37:2-39 and Psalm 45:1-2b and Psalm 60:8-9, with commentaries, occurs in 4QpPsa $\left(4 \mathrm{Q} 171\right.$ - col. IV:23-27). ${ }^{15}$ It is the only instance of

10.The plene writing of the word was simply a practice of the scribes.

11.Between 1939 and 1957, Joseph Ziegler of Würzburg published all 16 prophetical books in five volumes, of which Isaiah was the first to appear (Jellicoe 1989:18).

12.Jellicoe (1989:178) points out that 'Chester Beatty VII (965) is too fragmentary in this particular book [i.e. Isaiah, GJS] to be of effective assistance, but where its evidence is adducible it aligns itself with $A Q$, which, though not always in mutual agreement, tend to combine against $B^{\prime}$.

13.Cf. Van der Kooij (1997:14): 'Dominanter Zug in LXX ist das Interesse an Leitern, die das Gesetz außer Kraft zu setzen versuchen'.

14.Some key aspects of my contribution on the quotation from Psalm 45 in Hebrews 1 are repeated here. See Steyn 2004:1085-1103.

15.Steudel (1994) states:

Zwar entstand die Handschrift um die Zeitenwende, doch ist das Werk nicht zuletzt wegen Kol. $11,6-8$ in seiner Entstehung vor $70 \mathrm{v}$. Chr. anzusiedeln. Es handelt sich also um einen frühen Pescher. (p. 189) 
a quotation from Psalm 45(44) occurring in the DSS (Maier 1996). It thus relates only to vv. 1-2 of Psalm 45, whilst the section under discussion here in Ad Hebraeos is vv. 7-8 of Psalm 45. Apart from the fact that 11QPs (11Q5, col. XVII) merely contains the text of Psalm 45:13-32, another interesting parallel of the motif itself is also noticeable elsewhere in $11 \mathrm{QPs}^{\mathrm{a}}$ (559, v. 11): ' $\ldots$ and anoint me with holy oil, and set me as leader of his people, and chief of the sons of his covenant'. Further allusions might be present in 4QcommGen A (4Q252; $\mathrm{V}, 1-4)$, where there is talk of hope for a Davidic king with striking similarities between the 'sceptre or staff', the 'messiah of righteousness' and 'kingship of his people for everlasting generations' (García Martínez \& Tigchelaar 1997:504-505; Guthrie 2007:938). Among the Hebrew witnesses, the MT could be compared with the DSS fragment 11QPs ${ }^{d}$ (11Q8) (García Martínez \& Tigchelaar 1998:1182-1183; García Martínez, Tigchelaar \& Van der Woude 1998:70), which contains the section of Psalm 45:7-8, specifically the passage used by the author of Ad Hebraeos for his quotation. Although this fragment was not previously included in critical editions and variant listings (Flint 1997:42), it brings no new information as far as the text of the quotation is concerned and its reading is thus in agreement with that of the MT. The author of Ad Hebraeos might have known Psalm 45(44) via the early Jewish tradition. It probably already had messianic connotations. The author's LXX translation supported the messianic line of interpretation. He must have looked at the text himself and quoted from a section that had never been quoted before. Some possible factors might have led to the author of $\mathrm{Ad}$ Hebraeos using this particular section, either independently or in some combinations. The first clue is the occurrence of Psalm 45:1-2 quoted in 4Q171 among the pesharim of the DSS. He might have shared an exegetical tradition that included Psalm 45(44) as part of the texts studied and commented upon. The second clue may be provided by the heading of Psalm 44 in the LXX (Riggenbach 1992:22) and the fact that the Psalm contained messianic elements for the author of $\mathrm{Ad}$ Hebraeos (Schröger 1968:64). A third clue is to be found a few lines earlier in the context of Hebrews 1 when the author quoted 2 Samuel 7 - which we know was well known in the tradition. Several elements (throne, his kingdom, forever) from the kingdom motif might have provided the Stichwörter with the means by which the author found his passage (Kistemaker 1961:78; Schröger 1968:64-65). A conceptual connection with 2 Samuel 7:12 has thus also been evidenced in this instance, a connection that is made in 4QFlor 1:10-11 (Bateman 1995:17). The royal image elements (judicial sceptre, throne) and the ruler's eternal reign ${ }^{16}$ are now Christologically interpreted.

- Psalm 118:6 (4QpPs ${ }^{\mathrm{b}}$ = Ps 118:26-27): In particular, two documents among the DSS are of interest here. The first is

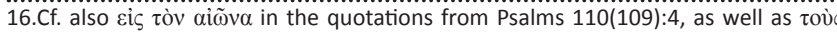

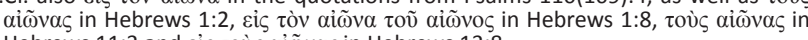

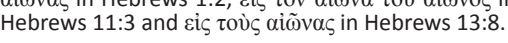

the fragment 4QpPs ${ }^{\mathrm{b}}$ (4Q84) that contains the text of Psalm 118:6 and that has a commentary on Psalm 118:26-27. ${ }^{17}$ The fragment dates from the second half of the first century BCE. It is stichometric and contains Psalms 91-118 - with Psalm 112, which follows Psalm 103, and with Psalms 104-111 missing (Flint 1993:40-41; Skehan 1964:313-322). A comparison of the Hebrew texts of Psalm 118:6 in this fragment with that of the MT shows an identical reading.

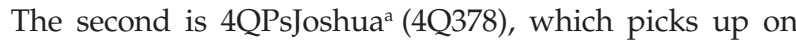
the same motif. ${ }^{18}$ Psalm 118(117) was initially only closely associated with Jewish festival services, such as the Passover, but was also gradually used during Easter in the early church (Grässer 1997:362; Kistemaker 1984:411; Thomas 1964/1965:319). ${ }^{19}$ Scholars suspect that particularly during the 'last remnant of the 7-day Jewish celebration of Passover', it was sung during the entire week following Easter Sunday (Kistemaker 1961:57). ${ }^{20}$

The closest resemblance between the quotations in $A d$ Hebraeos and the DSS are, however, four quoted texts in $\mathrm{Ad}$ Hebraeos that were already clearly quoted in the DSS. These are 2 Samuel 7:14 in Hebrews 1:5; Psalm 22:23 in Hebrews 2:12; Psalms 104:4 in Hebrews 1:7; and Habukkuk 2:3b-4 in Hebrews 10:37-38.

- 2 Samuel 7:14 (4QFlor = Is I:10, 12): The original intention of the promise in 2 Samuel 7 relates to King David's son, Solomon. However, a transition from understanding this passage merely in the sense of $a$ Davidic heir to that of the royal messianic heir is to be seen among the DSS in 4QFlor I, 11-12 ${ }^{21}$ (4Q174) and its commentary on 2 Samuel 7:11-14, which applies this passage to the royal messiah. The quotation, or rather 'loose paraphrase' (Washburn 2002:78), is followed by the comment (pesher) that 'he is "the shoot of David", who will arise with the Interpreter of the Law, who, [...] in Zi[on in the 1]ast days' (Allegro \& Anderson 1968:54; Bruce 1985:14). ${ }^{22}$ When comparing the Hebrew witnesses, the DSS Samuel fragments from cave 4 are of special interest and provide evidence of the Hebrew prototype for the LXX readings, which in turn differs from those of the MT. ${ }^{23} 4 \mathrm{QSam}{ }^{\mathrm{b}}$ (4Q52) represents one of the oldest manuscripts found among the DSS and dates

17.The same document (4Q173) also comments on Psalm 127:2-3, 5 and Psalm 129:7-8.

18.Translation: '... and do not be afraid, be strong and re[solute becau]se you will cause [this people] to take possession [ ... he will not] leave you or desert [you] (4Q378, frag.3, col. ii, vv. 10-11a) (García Martínez \& Tigchelaar 1998:746-747).

19.Werner (1959:57) argued similarly, saying that '[a]pparently this psalm citation belonged to the liturgy of synagogue and church'.

20.Kraus (1978:985) summarises the prominent place that Psalm 118(117) took during NT times:

...es (ist) durchaus verständlich, daß Ps 118 im Neuen Testament eine besondere Bedeutung gewinnen konnte. Die zahlreichen Zitierungen und Anklänge einzelner Aussagen an den 118. Psalm bestätigen, daß die Urgemeinde die überindividuelle und urbildliche Verkündigungskraft des alttestamentlichen Psalms aufgenommen und in ihren wesentlichen Aussagegehalt rezipiert hat.

21.For the initial reconstruction and the text (see Allegro 1958:350-354; Yadin 1959:95-98). For a discussion of the fragment (see Brooke 1985).

22.According to Guthrie (2007:929), 'The dominant use of 2 Sam. 7 in Jewish sources seems to be to emphasize especially the dynastic permanence of David's line (4Q252 V, 1-6; Sir 47:11, 22; Pss.Sol. 17:4)'.

23.Shenkel (1968:5-21) identified four major stages in the history of the Greek text: (1) the Old Greek, (2) proto-Lucian, (3) the Kaíye recension and (4) the Hexapla. Their importance regarding their Hebrew Vorlagen is self-evident. 
back to the end of the third century BCE (Flanagan 1992:958). That of 4QSam ${ }^{\text {h }}$ (4Q62) has been thought to exhibit a text superior to that of both the MT and LXX, whilst 4 QSam ${ }^{\mathrm{a}}$ (4Q51) seems to represent a text that is closer to the LXX and to that used by the writer of Chronicles. The MT is shorter than both $4 Q_{S a m}{ }^{\mathrm{a}}$ and the LXX and the latter two, in turn, are thus closer to each other (Charlesworth 2000:227-228). It is also interesting to note that Josephus agrees with 4 QSam ${ }^{\mathrm{a}}$ in six places against the MT and the LXX. Furthermore, Josephus, 4QSam ${ }^{\mathrm{a}}$ and the LXX share about three dozen readings against the MT (Charlesworth 2000:229). Unfortunately for this study, none of the extant fragments from 4QSam contain the text of 2 Samuel 7:14. It breaks off at 7:6-7 and continues again from 7:22-9 (Cross et al. 2005:4; García Martínez \& Tigchelaar 1997:352-353). The other remaining comparative Hebrew text from the DSS is that of 4QFlor I:11 (4Q174).

- Psalm 22:23 (1QH 12:3): Although the section quoted in Hebrews 2:12 has not been preserved among the DSS, Psalm 22 is quoted a few times in the Hodayot. ${ }^{24}$ None of those quotations coincides with Psalm 22:2, the verse that is quoted in the Synoptic Gospels, or with Psalm 22:19, which is quoted in John 19:24. However, one of these cases does include Psalm 22:23-24, which is quoted in $1 \mathrm{QH} 12: 3$ - the same text that is also cited in Hebrews 2:12. Nonetheless, the variant text of $1 \mathrm{QH}$ throws no light on the readings of Ad Hebraeos or on that of the LXX, which are clearly identical (De Waard 1965:62-63). ${ }^{25}$ Another case is found in 1QH 2:28, where Psalm 22(21):15, 23 is quoted. This verse is part of a congregational hymn (1QH 2:20-30), or a 'song of thanksgiving', about divine election. ${ }^{26}$

- Psalm 104:4 (1QH 1:11): Psalm 104 was probably used during the Jewish synagogue liturgies on Friday evenings and Sabbath mornings (Kistemaker 1961:23, 1984:41; Werner 1959:150). Psalm 104 verse 4, which is quoted in Hebrews 1:7, was also alluded to by early Judaism in the DSS. Psalms 104:4 is the most widely covered among the findings of the DSS from all the Psalm quotations that occur in Ad Hebraeos. Three different fragments contain the verse used in the quotation of Hebrews 1:7: 4QPs ${ }^{\mathrm{d}}$ (4Q86) has the section of Psalms 104:1-5 preserved; 11QPs ${ }^{a}$ (11Q5) contains the section of Psalms 104:1-6, and 4QPs (4Q93) contains Psalms 104:3-5. The readings of the three DSS fragments and that of the MT are very close. $4 \mathrm{QPS}^{\mathrm{d}}$ and the MT are identical, whereas 11QPs ${ }^{a}$ reads 'flaming fire' (similar to the LXX Ps 103:4: $\pi \tilde{\nu} \rho$ $\varphi \lambda \dot{\varepsilon} \gamma o v$ ), not 'flames of fire', and $4 \mathrm{QPs}^{1}$ reads 'messenger' and 'servant' in the singular, not the plural. There are also three places where possible allusions to this text were identified among the DSS. The first is within the section 1QS 1:16-2:25, which

24.Against Guthrie (2007:948), who identifies only 'a faint echo of our passage' at $1 \mathrm{QH} \mathrm{H}^{\mathrm{a}} \mathrm{XIII}, 15 \mathrm{~b}$

25.Guthrie (2007:948) pointed out, however, that the reading of Psalm 22(21):16 in the Psalms scroll from Nahal Hever matches that of the LXX against the MT and the Targum on the Psalm.

26.Fabry (1988:300) drew attention to the fact that this is one of very few places where a motif from the lamentation part is combined with a motif from the praise section. describes the ceremony of the feast of the renewal of the covenant (Vermes 1977:178). The listed passage (1QS 1:21-22) is questionable, however, as it only talks about the priests and the Levites who will 'recite the just deeds of God in his mighty works'. The second is within 4QWorks of God (4Q392). ${ }^{27}$ The third case, from the Hodayot (1QH 1:10b-12) can indeed be identified as an allusion. ${ }^{28}$ It was thus in principle not an unknown phrase. Furthermore, the broader motif of the angels being flames of fire, and also spirits and winds, was a known motif among the community at Qumran. ${ }^{29}$

- Habukkuk 2:3b-4 (1QpHab 7:9-16): The interpretation of Habakkuk played an important role in early Judaism - especially at the DSS community with their Pesher Habakkuk (1QpHab). This is not the place to discuss the document as a whole, or even the whole chapter; instead we will focus only on the verses that are relevant for the purposes of this investigation. The DDS community interpreted the 'reader' of Habukkuk 2:2:

as the Teacher of Righteousness and applied Habakkuk 2:3b and $4 \mathrm{~b}$ to the doers of the Law in Judah, whom God will deliver from condemnation because of their suffering and their faithfulness or loyalty to the Teacher of Righteousness (1QpHab 6:12-8:3) (Silva 1993:640; cf. also Guthrie 2007:982; Van der Kooij 1997:19).

Steyn (2011b:312-313) earlier summarised:

Especially 1QpHab 7:5-8:3 deals with the pesher on Habukkuk 2:3-4, which is strongly eschatologically interpreted ... Suffice it to say that it certainly is interesting that column 8 has references to the office of the high priest who co-operated politically with the Romans in order to gain personal wealth. These contrasts between the Teacher of Righteousness and the corrupt high priestly office at the end of the Hasmonean period, certainly situate Ad Hebraeos' Jesus as High Priest according to the order of Melchizedek (King of Righteousness) within an interesting eschatological setting. ${ }^{30}$

Another text from the DSS that is of interest for the reading of Habukkuk 2:3b-4 is that of 1QpHab 7, 9-17 (cf. García Martínez \& Tigchelaar 1997:16-17) when stripped of its commentary.

\section{Hermeneutical importance}

Steyn (2003a:500) concluded previously that:

... the quotation from Psalm 8:5-7 in Hebrews 2:6-8a is the first quotation encountered in Ad Hebraeos where the author presents a brief explanation, an exegetical exposition or commentary, on the passage that he quoted (Ellingworth 2000:144; Guthrie

27.4QWorks of God reads: '9. [... wi]nds and lightning [... the ser]vants of the holy of ho[lies] going out before him ...' (García Martínez \& Tigchelaar 1997:788-789).

28.1QH 1:10b-12 reads: '10b. ... powerful spirits, according to their laws, before 11. they became $\mathrm{h}[\mathrm{oly}]$ angels [...] eternal spirits in their realms: luminaries according to their mysteries, 12. stars according to [their] circuits, [all the stormy winds] according to their roles, lightning and thunder according to their duties ...' (García Martínez \& Tigchelaar 1997:158-159).

29.Compare, for example, CD-A II (=4Q266 $2 \mathrm{II})$ : '5b. ... strength and power and a great anger with flames of fire 6 . by the <hand > of all the angels of destruction...' Also

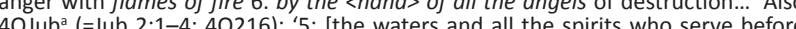
$4 Q J_{u b}$ (=Jub 2.1-4, 4Q216): "5: [the waters and all the spirits who serve before him: the angels of the an [gels of the of the [clouds]' (García Martínez \& Tigchelaar 1997:552-553, 460-461).

30.There might also be a possible allusion to Habukkuk 2:3-4 in 1QH 5:27. 
2007:944). ${ }^{31}$ More cases of similar expositions of the Scripture quoted by him, would be encountered later in his work, e.g. when he quotes Psalms 95(94) and comments on it in Hebrews 3:7-4:11 and when he quotes Psalms 40(39) in Hebrews 10:5-10. This technique shows some resemblances with the pesher method as found in the DSS. (Schröger 1968:25, 258, 260; Weiss 1991:194)

The thought patterns in the exposition of the commentary stand thus in a chiastic relationship with those of the quotation itself. (A similar situation will be seen later as well in the commentary on Ps 95:7-11 in Heb 3-4). The text of the commentary is a reflection, a reversed image as if in a mirror, of the text of the quotation itself. (Steyn 2008:337)

The style of using scripture here is reminiscent of that in the DSS, especially passages such as 1QpHab 12:6-10 and CD 4:13-14 (Braun 1966:245; Gärtner 1954:12). It displays the characteristics of the midrash-pesher (Combrink 1971:29) and is structured as follows: introductory formula, quotation and a fairly extensive commentary that contains words and phrases from the quoted text that are being explained within the commentary itself. ${ }^{32}$

\section{Theological importance}

It is striking that some of the prominent motifs that surface in Ad Hebraeos show close parallels with similar motifs in the DSS. At least six of the quoted texts in Ad Hebraeos relate to prominent themes and motifs to be found in the DSS. These include the motifs of rest (Ps 95:7-11; 2 Sm 7:14), the royal priest (Gn 14:17-20; Ps 110:4), the new covenant (Jr 31[38]:31-34) and the law at Sinai (Dt 9:19).

- Psalms 95(94):7-11 and 2 Samuel 7:14 (vid. 4QFlor I:7; 4 Q372 and the motif of rest): Although it has been observed before that there are no explicit quotations from Psalms 95(94) in our existing corpus of early Jewish and Christian literature, there seem to be at least some possible allusions to Psalm 95(94) in the pre-Ad Hebraeos literature. It is particularly the motifs of rest and of testing, as found in this psalm, that were part of a number of familiar and recurring motifs in early Judaism and early Christianity. It is thus not surprising that allusions to the section quoted from Psalms 95(94):7-11 by the author of $\mathrm{Ad}$ Hebraeos are thus to be found elsewhere (McLean 1992:75). ${ }^{33}$ These motifs also surfaced at Qumran. In 4QFlor 1:7 (4Q174), the motif of rest (from enemies) is picked up from the quotation of 2 Samuel (2 Kgdms) 7:11. Interesting is the occurrence of this motif in some kind of 'Joseph tradition' as surfaces in 4QapJoseph ${ }^{\text {a }}(4 \mathrm{Q} 372)^{34}$ and in Joseph and Aseneth 8:9 (first century BCE to

\section{Attridge (2004) states:}

While exegesis in the catena of ch. 1 was implicit, it is here explicit and the verses immediately following the citation of the psalm constitute a brief midrash on the text. (p. 204)

32.It is difficult to determine whether this also applies to PVindob as only a small fragment is left, containing the text of the Ad Hebraeos commentary (2:9-11).

33.Psalm 95:7 is alluded to in 1QS 5:26; Psalm 95:10 in 1QH 1:22, 1QS 5:4 and Barn. 8:5; and Psalm 95:11 in Odes Sol. 20:8.

34.Frag. I:5b-6 reads: '... [they did not enter] Israel. And he exterminated them from the land [...from the place ...they did not allow them to rest]' (García Martínez \& Tigchelaar 1998:734-735) second century CE). ${ }^{35}$ The motif of the testing at Massah and Meribah, in turn, surfaces in 4QTest (4Q175) v. 15 in a quotation from Deuteronomy $33: 8-11 .{ }^{36}$ It is also interesting to note - in light of the allusions in 1QS 5:4 and 5:26 above, that the DSS community often referred to themselves as 'covenant-keepers' (e.g. 1QS 5:2). Familiarity with Psalm 95(94) in liturgical settings can also be assumed. Psalms 95(94) and 96(95) were apparently known as Psalms for the invitation of worship, with Psalm 95(94) possibly 'regarded as a preamble of services on Friday evening and Sabbath morning' (Kistemaker 1961:35). ${ }^{37}$ Turning to the Hebrew textual traditions, it should be noted that some fragments were found among the DSS that contain parts of Psalm 95:7-11: 4QPs ${ }^{\mathrm{m}}$ (4Q94) has the text of Psalm 95:3-7, whilst 1QPs ${ }^{\text {a }}$ (1Q10) (Barthélemy \& Milik 1955:69) contains Psalm 95:11-96:2 (García Martínez \& Tigchelaar 1997:5-6, 283). ${ }^{38}$ This covers at least the beginning and the end of the section used by the author of Ad Hebraeos for his quotation. When comparing the evidence from the Hebrew traditions as found in the DSS and the MT, the surviving readings are identical.

- Genesis 14:17-20 and Psalm 110:4 (vid. 11QMelch and the motif of the royal priest): Thirteen fragments were found among the DSS - the remains of an eschatological midrash, known as the Melchizedek document (11QMelch/11Q13). There is an interesting parallel regarding the motif of a royal priest to be found in 11QMelch. ${ }^{39}$ Its central motif, however, 'is the expectation of the coming of Melchizedek as the Heavenly Judge in the Last Judgment' (Flusser 1988:186). Although Melchizedek and the archangel Michael are never explicitly equated in the Qumran literature, we find Melchizedek pictured here as being identical with the archangel Michael. ${ }^{40} \mathrm{He}$ is the deliverer and the chief of the heavenly beings (literally 'gods', elohim) (Vermes 1977:82, 184). 11QMelch pictures Melchizedek as 'captain of the host of heaven, suggesting that he is to be

35..... let her enter your rest which you have prepared for your chosen ones (Cf. Burchard 1985:213; also Fischer 1978:122). Gzella (2002:165), too, pointed to the similarities and states:

Der sehr enge sprachliche Anklang an die Septuaginta-Fassung von Ps 95 (94), 11

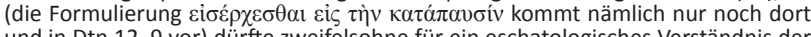
und in Dtn 12, 9 vor) dürfte zweifelsohne für ein eschatologisches Verständnis der Psalmenstelle zumindest zur Abfassungszeit des Romans sprechen. Zusammen mit Hebr 3, $7 \mathrm{ff}$ bezeugt dies eine verbreitete eschatologische Rezeption des Ruhemotivs im griechischen Psalter, an dem sich die Verfasser dieser Texte orientiert haben.

$36 . .$. whom I tested at Massah, and with whom I quarrelled about the waters of Meribah ...' (García Martínez \& Tigchelaar 1997:356-357).

37.According to Kistemaker (1961:35), the 'practice undoubtedly stemmed from the Temple ritual which in later years was gradually taken over in the Synagogue'. The controversial viewpoint of Goulder (1998:109) is similar when he sees the function of Psalm 95(94) as part of the morning liturgy in churches from early times:

The psalms in Book IV are numbered 90-106, and we should therefore have the same mnemonic as with the Songs: if they were a festal sequence, evening and morning, the even-numbered psalms would have to fall in the evening and the odd numbers in the morning. This time we have three probable morning psalms, 95, 97 and 101. Psalm 95, the Venite, has been used as a morning psalm in churches from early times: its challenge, 'Today, if ye hear his voice, Harden not your heart', seems appropriate in the morning, when there is time for such resolutions (95.7).

38.Dahmen (2003) also finds evidence of $11 \mathrm{QPs}^{\mathrm{a}}$ (11Q5) that contains Psalm 95:11, but this is debatable.

39.Cf., for instance 11QMelch: 'But, Melchizedek will carry out the vengeance of God's judgements [on this day, and they shall be freed from the hands] of Belial and from the hands of all the sp[irits of his lot]' (col ii, 13); and '[y] our God is [Melchizedek, who will fr] ee [them] from the hand of Belial' (col ii, 24-25).

40.The depicting of Melchizedek in 11QMelch as an angelic being might hold important clues for understanding what the Son as heavenly being and Melchizedek have in common - such as that both abide forever. 
numbered among the archangels', and as a seated judge, like Moses, on a throne of glory, 'exercising judgment over the destinies of men' (Russell 1987:43). The same similarity between the roles of Melchizedek and the archangel Michael is also to be found in the War Scroll (1QM 9.14-16). García Martínez suspected that Melchizedek might be identified in the Aramaic Apocalypse (4Q246) with the 'Son of God'. Flusser had a similar suspicion that there could have been a contamination between the two personages Melchizedek as a mythical figure and as the Son of Man (Flusser 1988:191). Along the same lines, Vermes is of the opinion that Melchizedek was probably also to be identified with the 'chief of the Sons of Light' in the Testament of Amram (4QAmram) (Vermes 1977:70). The elements of Melchizedek being ruler of the host of heaven, judge or possibly 'chief of the Sons of light' do not fit those in Hebrews 7:1-4. The closest might be the suspicion that 'Son of God' in 4Q246 refers to Melchizedek and that the 'Son of God' is identified as the 'king', as in Hebrews 7:1-2. However, such an argument would be built on too many presuppositions; moreover, there would be too many remaining elements in Hebrews 7:1-4 that are not found in the Qumran literature. ${ }^{41}$

- Jeremiah 31(38):31-34 (vid. CD 6:19; 8:21; 19:33; 20:12 and the motif of the new covenant): Scholarship has only fairly recently paid attention to the role of Jeremiah 31:31-34 and the new covenant motif within Jewish tradition. The reader is referred to these investigations (cf. Lichtenberger \& Schreiner 1996:272-290) - with only a few general remarks that will suffice for this study. Traces of the renewal of the covenant are already present in passages such as Ezekiel 37:23. ${ }^{42}$ The motif from Jeremiah 31(38):31-34 was taken up mainly by two groups in the later tradition: the DSS community (without explicit reference to Jeremiah 31[38] though ${ }^{43}$ and the early Christians. However, it is especially in the DSS community where the expectation of a new covenant was present. ${ }^{44}$ They understood themselves as people of the New Covenant, although this covenant 'was for them nothing more than the Mosaic Covenant with strong legalistic tendencies' (Thompson 1989:580). A possible intertextual occurrence to Jeremiah 31(38) was identified in 11QTa 29:7-8 (11Q19) (Brooke 1998:53). In particular, the Damascus Scroll (CD) refers explicitly to those who entered into a new covenant in Damascus. The motif of a new covenant is an important motif in CD. ${ }^{45}$ Two

41.Ellingworth (2000:283) is sceptical about Qumran influence of a kingly and priestly messiah on Hebrews. He argues that the bitter schism between Jerusalem and Qumran on the priesthood would require the author of Hebrews to address either one party or the other.

42.Thompson (1989:579) sees Jeremiah $31: 31-34$ as 'the only reference to a new covenant in the OT'.

43.Cf. Weiss (1991:446): 'nur in Gestalt der technischen Wendung vom "Eintreten in den Neuen Bund"... also im Sinne des Eintritts in die Gemeinde'. There are thus no grounds to assume that Hebrews received this motif from the DSS community or that he writes polemically against it.

44.CD 6:19; 8:21; 19:33-34; 20:12; 1QpHab 2:1-4; 1Q28b 3:25-26; 5:21-22; 1 Q34 3 5-6. Guthrie (2007:971) also adds 1 QS I,16, 18, 20, 24; 1QS II,10. With regard to the occurrences in the Damascus Document, Christiansen (1998.82) makes the po point that "The expression "new covenant is notably ambiguous. The question is an allusion to Jeremiah, it is of note that the context there is covenant as "new law" with a different quality to the covenant relationship'.

45.Cf. CD 6:19; 8:15, 21; 9:28, 37; 19:33, 34; 20:12 fragments of the Damascus Scroll were also discovered in Cairo - even before its discovery at Qumran. The final columns of CD contain a liturgy for the renewal of the covenant (Milik 1959:551-552, 1972:135), which took place once a year when all members of the community underwent evaluation (Lundbom 1992:1090). It is debated whether a reference to a 'new covenant' originally appeared also at a lacuna in 1QpHab 2:3, the Pesher Habakkuk (Lundbom 1992:1090).. ${ }^{46}$ For many years it was assumed that this shorter version was the result of a deliberately abbreviated Greek translation - an opinion that is still supported by some scholars today. ${ }^{47}$ Most scholars, however, are of the opinion that the shorter Greek version is rather the result of a Hebrew text that is both shorter and superior to that of the MT (Becking 1994:147; Soderlund 1985:247). ${ }^{48}$ Proof of this shorter text has been found among the DSS, with the Hebrew fragment of Jeremiah (4QJer ${ }^{\mathrm{a}, \mathrm{b}}$ ) supporting some of these omissions (Geisler \& Nix 1986:368). There are, furthermore, indications of a closer relation between the LXX and the Hebrew tradition as represented in 4QJer, such as four verses that are omitted and one that is transposed in Jeremiah 10 of 4 QJer $^{\mathrm{a}}$ (Geisler \& Nix 1986:374). However, traces of the longer version were also found among the DSS, which testifies to the availability of both the shorter and longer forms of the text. The MT and LXX translation of Jeremiah are thus probably based on different recensions of the Hebrew, according to some scholars. ${ }^{49}$ The oldest manuscript among those of the DSS, Jeremiah (4QJer $\left.{ }^{\mathrm{a}}\right)$, dates back to the end of the third century BCE (Collins 1992:89). Unfortunately, neither this fragment nor any of the other Jeremiah fragments that were found among the DSS contain the text of Jeremiah 31(38):31-34..$^{50}$

- Deutoronomy 9:19 (vid.4Q378 and the motif of the law on Sinai): Although an exact quotation from Deuteronomy 9:19 is not found in early Jewish literature, the motif of fear and trembling when the law was received was, as one can expect, not an unknown motif. Apart from appearing in Psalm 18(17) and in Psalm 77(76), it surfaces furthermore in the DSS in 4QPsJoshua a (4Q378)..$^{51}$ In addition, 4QLights 2:8 refers to Moses who received the law.

46.For an exposition of $\mathrm{Jr}$ 31:31-34 in rabbinic tradition, see Lichtenberger and Schreiner (1996:272-290)

47.Cf. G. Fischer (1997:328): 'Viel eher kann man in G [i.e. LXX, GJS] weitgehend das Produkt redaktioneller oder herausgeberischer Tätigkeit sehen, die sich mit der ohnehin zu leistenden - Übersetzung auf leichte Weise harmonisch verbinden ließ'. Fischer points out that the debate about the original text is thus still going on and he challenges the reasons listed for an older and a shorter Hebrew Vorlage from which the LXX was translated.

48.Stipp (1994), too, stated:

JerG* ist eine zuverlässige Zeugin eines nichtmasoretischen hebräischen Originals Die Arbeitsweise ihrer Urheber hat den Vorteil daß die Vorlage zumeist mit befriedigender Sicherheit aus der griechischen Wiedergabe rekonstruiert werden kann. (p. 59)

49.According to Thompson (1989:119), '[i]t is not possible to say at what point the Hebrew tradition on which the LXX was based diverged from that on which MT was based'.

50.The situation did not change since the time of Ahlborn (1966:75): '[wir haben] keinen weiteren Beleg aus dem Jeremiabuche'.

51.It reads: 'And the children of Is[rael ...] [... wh]ich YHWH established with [...] [... fe] ar of you and dread of you [ ... ]' (Frag. 14, 3b-5) (García Martínez \& Tigchelaar 1998:746-747). 


\section{Socio-religious importance}

The Canticum Mosis probably played a particular role during the cultic rituals and liturgical actions of some groups in early Judaism during the celebration of some festivals. At least two such festivals might have had connections with it. The first is the controversial festival of the renewal of the covenant. Those who accept its existence understand it as an annually repeated sacred act of the renewal of the covenant, attested to in the DSS (cf. the Manual of Discipline 2:15). If it is accepted, however, then the role that the Canticum Mosis played in it at Qumran during the liturgical function of this song should certainly be taken into account when pondering its position in early Judaism and early Christianity. One can thus assume that in groups that saw themselves as 'covenant communities' this Canticum Mosis would have had an important liturgical role. The liturgical connections of the Canticum Mosis and Psalm 135 with the festival ${ }^{52}$ cult of the Israelite covenant community ${ }^{53}$ might throw some light on the covenant motif as found in Ad Hebraeos. However, the Canticum Mosis was probably also used during the festival of the Day of Atonement, as testified in a Samaritan liturgical poem (Falk 1998:164). This liturgical use during some festivals has important implications for the Vorlage of the quotation in Hebrews 1:6.

More likely are the liturgical connections that were made by scholars such as Kistemaker. Known existing liturgies from Jewish groups that withdrew from society, such as the Sabbath or Angel Liturgy with its 13 Sabbaths, discovered among the DSS, come to mind here (cf. Steyn 2003c:11071128, 2011a:429-450). 'The similarities between these pairs of quoted texts with their themes and the themes found in the Sabbath, might point in the direction of a similar group that could have shared a similar theology (such as their view on angels, the temple, Sabbath, covenant, etc.), as well as sharing similar hermeneutics and techniques of reinterpretation of Scripture (such as pesharim, etc.)' (Steyn 2008:331). Apart from noting these similarities, however, no concrete evidence exists that might connect the readers of Ad Hebraeos with such a Jewish group and any such connection would thus be speculative.

\section{Conclusion}

Scholars have already pointed to some similarities between the DSS and Ad Hebraeos (cf. Buchanan 1972; Kosmala 1959; Pixner 1992:167-178; Spicq 1952, etc.). It is not surprising to find some quotations, allusions and motifs that appear in both the NT and in the DSS. This does not mean at all that the author of Ad Hebraeos used the DSS as Vorlage for his quotations or that he had some direct connection with the community in the Qumran vicinity. However, what is clear is

52.According to Barth (1962:71), "The author shows an unmistakable interest in the festivals, the holy assemblies, the cultic actions and institutions of God's people'.

53.Weiser $(1982: 788,789)$ pointed to the fact that Psalm 135 was literary dependent on other literary sources and that:

we can clearly see that Psalm 135 is in all its parts a liturgical hymn which was appointed to be recited antiphonally at the festival cult of the Israelite covenant community. that there seems to be a common theology and common motifs that are shared by both the Qumran covenanters and the author of Ad Hebraeos - if not also by the group to whom he wrote. The role of angels, Moses, Melchizedek, a heavenly sanctuary that is different from the temple in Jerusalem, the expectation of a royal Davidic messiah installed as the Son of God and of a royal priest connected with judgment, a new covenant and a common core of textual quotations are all elements that are to be found in both the DSS community (or communities) and in Ad Hebraeos. Although several of these motifs are also present in other literature apart from the DSS, one can cautiously imagine a similar Jewish sectarian matrix $x^{54}$ from which certain Christian converts might have come such as the author of Ad Hebraeos himself. ${ }^{55}$ Many DSS (third century BCE to first century $\mathrm{CE}$ ) are interpretations and reworkings from older biblical texts. Their biblical interpretation shows similarities to that of the author of $\mathrm{Ad}$ Hebraeos. Biblical passages were taken and reworked.

These commonalities require that the DSS should be taken into account as well alongside other literature where similar motifs occur. This implies, in turn, that the DSS should be taken more seriously in studies on Ad Hebraeos than might be the case in the other NT books. It relates particularly to the Psalter, ${ }^{56}$ from which a substantial number of the explicit quotations in Ad Hebraeos were taken (Kistemaker 1961:14, 1984:9; Koch 1999:465).

\section{Acknowledgements Competing interests}

The author declares that he has no financial or personal relationships that may have inappropriately influenced him in writing this article.

\section{References}

Ahlborn, E., 1966, 'Die Septuagintavorlage des Hebraerbriefes', PhD dissertation, Georg-August-Universität, Göttingen.

Allegro, J.M., 1958, 'Fragments of a Qumran Scroll of Eschatological Midrâšîm', JBL 77 , 350-354. http://dx.doi.org/10.2307/3264674

Allegro, J.M. \& Anderson, A.A. (eds.), 1968, Qumrân cave 4.I (4Q158-4Q186) (DJD V), Clarendon, Oxford.

Attridge, H.W., 1989, The Epistle to the Hebrews (Hermeneia), Fortress Press, Philadelphia, PA.

Attridge, H.W., 2004, 'The Psalms in Hebrews', in S. Moyise \& M.J.J. Menken (eds.), The Psalms in the New Testament, pp. 197-212, T\&T Clark, London.

Barth, M., 1962, 'The Old Testament in Hebrews: An essay in Biblical hermeneutics', in W. Klassen \& G.F. Snyder (eds.), Current issues in New Testament interpretation. Essays in honor of Otto A. Piper, pp. 53-78, SCM Press, London.

Barthélemy, D. \& Milik, J.T., 1955, Qumran cave I (DJD I), Clarendon Press, Oxford.

Batdorf, I.W., 1972, 'Hebrews and Qumran: Old methods and new directions', in E.H. Barth \& R.E. Cocroft (eds.), Festschrift to honor F. Wilbur Gingrich, pp. 16-35, Brill, Leiden.

Bateman, H.W., 1995, 'Two first-century messianic uses of the OT: Heb 1:5-13 and 4QFlor 1.1-19', JETS 38(1), 11-27.

Becking, B., 1994, 'Jeremiah's book of consolation: A textual comparison. Notes on the Masoretic text and the old Greek version of Jeremiah XXX-XXXI', VT 44(2), 145-169.

54.Phrase indebted to T. Lim during personal discussion at the University of Edinburgh on 14 July 2006.

55.Please note the word 'similar'. It is not at all the intention of this study to propose that the author of Hebrews and the DSS community/ies had any direct contact.

56.E. Tov pointed to these during the August 2000 Studiorum Novi Testamenti Societas conference in Tel Aviv. 
Braun, H., 1966, Qumran und das Neue Testament I, Mohr, Tübingen.

Brooke, G.J., 1985, Exegesis at Qumran. 4Qflorilegium in its Jewish context (JSOTSup 29), JSOT Press, Sheffield.

Brooke, G.J., 1998, 'Shared intertextual interpretations in the Dead Sea Scrolls and the New Testament', in M.E. Stone \& E.G. Chazon (eds.), Biblical perspectives: Early use and interpretation of the Bible in the light of the Dead Sea Scrolls, pp. 35-58, Brill, Leiden.

Bruce, F.F., 1962/1963, “"To the Hebrews" or "to the Essenes"?', NTS 9, 217-232. http://dx.doi.org/10.1017/S0028688500001740

Bruce, F.F., 1985, The Epistle to the Hebrews (NICNT), Eerdmans, Grand Rapids, MI.

Buchanan, G.W., 1972, To the Hebrews (AB 36), Doubleday, New York.

Burchard, C., 1985, 'Joseph and Aseneth', in J.H. Charlesworth (ed.), The Old Testament Pseudepigrapha, vol. 2, pp. 177-247, Doubleday, New York.

Charlesworth, J.H., 2000, Miscellaneous Texts from the Judaean Desert (DJD XXXVIII), Clarendon Press, Oxford.

Christiansen, E.J., 1998, 'The consciousness of belonging to God's covenant and what it entails according to the Damascus document and the community rule', in F.H. Cryer \& T.L. Thompson (eds.), Qumran between the Old and New
(JSOTSupSer 290), pp. 69-97, Sheffield Academic Press, Sheffield.

Collins, J.J., 1992, 'Dead Sea Scrolls', in D.N. Freedman (ed.), The Anchor Bible dictionary, vol. 2., pp. 85-101, Doubleday, New York.

Combrink, H.J.B., 1971, 'Some thoughts on the Old Testament citations in the Epistle to the Hebrews', (Ad Hebraeos: Essays on the Epistle to the Hebrews), Neotestamentica 5, 22-36.

Cook, J., 1989, 'Orthographical peculiarities in the Dead Sea Biblical Scrolls', RevQ 14(2), 291-303.

Cook, J., 1992, 'On the relationship between 11QPS and the Septuagint on the basis of the computerized data base (CAQP)', in G.J. Brooke \& B. Lindars (eds.), Septuagint, Scrolls and Cognate Writings. Papers presented to the International Symposium on the Septuagint and its Relations to the Dead Sea Scrolls and Other Writings (Manchester 1990), pp. 107-130, Scholars Press, Atlanta, GA.

Cook, J., 1994, 'The Orthography of some verbal forms of 1QIsaa', in G. Brooke (ed.) New Qumran Texts \& Studies. The Proceedings of the First Meeting of the International Organization for Qumran Studies, Paris 1992, Studies on the Texts of the Desert of Judah 15, pp. 133-147, Brill, Leiden.

Cross, F.M., Parry, D.W., Saley, R.J. \& Ulrich, U. (eds.), 2005, Qumran cave 4.XII: 1-2 Samuel (DJD XVII), Clarendon, Oxford.

Dahmen, U., 2003, Psalmen- und Psalter-Rezeption im Frühjudentum. Rekonstruktion Textbestand, Struktur und Pragmatik der Psalmenrolle 11QPs aus Qumran, Brill, Leiden.

De Waard, J., 1965, A comparative study of the Old Testament text in the Dead Sea Scrolls and in the New Testament (STDJ 4, ZWO), Brill, Leiden.

Ellingworth, P., 2000, The Epistle to the Hebrews (NIGTC), Eerdmans, Grand Rapids, MI.

Fabry, H.-F., 1988, 'Die Wirkungsgeschichte des Psalms 22', in J. Schreiner (hrsg.) Beiträge zur Psalmenforschung. Psalm 2 und 22, pp. 279-317, Echter Verlag, Würzburg.

Falk, D.K., 1998, Daily, Sabbath, and festival prayers in the Dead Sea Scrolls, Brill, Leiden.

Fernández Marcos, N., 2000, The Septuagint in context. Introduction to the Greek version of the Bible, Brill, Leiden.

Fischer, G., 1997, 'Zum Text des Jeremiabuches', Biblica 78(3), 305-328.

Fischer, J., 1930, In welcher Schrift lag das Buch Isaias den LXX vor? Eine textkritische Studie (BZAW 56), Alfred Toepelmann, Giessen.

Fischer, U., 1978, Eschatologie und Jenseitserwartung im hellenistischen Diasporajudentum, Walter De Gruyter, Berlin.

Fitzmyer, J.A., 1968, 'Jewish Christianity in acts in light of the Qumran Scrolls', in L.E. Keck \& J.L. Martyn (eds.), Studies in Luke-Acts: Essays presented in honour of Pau Schubert, pp. 233-257, Abingdon Press, Nashville.

Flanagan, J.W., 1992, 'Samuel, book of 1-2', in D.N. Freedman (ed.), The Anchor Bible dictionary, vol. 5, pp. 957-965, Doubleday, New York.

Flint, P.W., 1993, 'The Psalters at Qumran and the book of Psalms', PhD dissertation, University of Notre Dame.

Flint, P.W., 1997, The Dead Sea Psalms Scroll and the book of Psalms (STDJ 17), Brill, Leiden.

Flusser, D., 1988, 'Melchizedek and the son of man', in D. Flusser (ed.), Judaism and the origins of Christianity, pp. 186-192, Magnes, Jerusalem.

García Martínez, F. \& Tigchelaar, E.J.C. (eds.), 1997, The Dead Sea Scrolls study edition vol. 1, 1QI-4Q273, Brill, Leiden.

García Martinéz, F. \& Tigchelaar, E.J.C. (eds.), 1998, The Dead Sea Scrolls study edition, vol. 2, 4Q274-11031, Brill, Leiden.

García Martinéz, F., Tigchelaar, E.J.C. \& Van der Woude, A.S. (eds.), 1998, Qumran cave 11 (11Q2-18, 11Q20-31) (DJD XXIII), Clarendon Press, Oxford.

Gärtner, B., 1954, 'The Habakkuk commentary (DSH) and the Gospel of Matthew', StTh 8, 1-24. http://dx.doi.org/10.1080/00393385408599746

Geisler, N.L. \& Nix, W.E., 1986, A general introduction to the Bible, revised and expanded, Moody Press, Chicago, IL.

Goulder, M.D., 1998, The Psalms of the return (Book V, Psalms 107-150) (JSOT SuplSer 258), Sheffield Academic Press, Sheffield.
Grässer, E., 1964, 'Der Hebräerbrief 1938-1963', ThR 30, 138-236. [Reprinted in: Evang, M. \& Merk, O. (hrsg.), 1992, Erich Gräßer. Aufbruch und Verheißung. Gesammelte Aufsätze zum Hebräerbrief. Zum 65. Geburtstag mit einer Bibliographie des Verfassers, Walter de Gruyter, Berlin, pp. 1-99].

Grässer, E., 1997, An die Hebräer. 3. Teilband. Hebr 10, 19-13,25 (EKK XVII/3), Benziger Verlag, Zürich.

Guthrie, G.H., 2007, 'Hebrews', in G.K. Beale \& D.A. Carson (eds.), Commentary on the New Testament use of the Old Testament, pp. 919-995, Baker Academic, Grand Rapids, MI.

Gzella, H., 2002, Lebenszeit und Ewigkeit. Studien zur Eschatologie und Anthropologie des Septuaginta-Psalters (BBB 134), Philo, Berlin.

Høgenhaven, J., 1998, 'The Isaiah Scroll and the composition of the book of Isaiah', in F.H. Cryer \& T.L. Thompson (eds.), Qumran between the Old and New Testaments (JSOTSupSer 290), pp. 151-158, Sheffield Academic Press, Sheffield.

Jellicoe, S., 1989, The Septuagint and modern study, Eisenbrauns, Winona Lake, IN.

Karrer, M., 2002, Der Brief an die Hebräer. Kapitel 1,1-5,10 (ÖTKNT 20/1), Gütersloher Verlagshaus, Gütersloh.

Karrer, M., 2006, 'The Epistle to the Hebrews and the Septuagint', in W. Kraus \& R.G. Wooden (eds.), Septuagint research. Issues and challenges in the study of the Greek Jewish scriptures (SBL 53), pp. 335-353, Society of Biblical Literature, Atlanta, GA.

Karrer, M., 2008, Der Brief an die Hebräer. Kapitel 5,11-13,25 (ÖTKNT 20/2), Gütersloher Verlagshaus, Gütersloh.

Kistemaker, S.J., 1961, The Psalm citations in the Epistle to the Hebrews, Wed. G. van Soest N.V., Amsterdam.

Kistemaker, S.J., 1984, New Testament commentary Exposition of the Epistle to the Hebrews, Baker Book House, Grand Rapids, MI.

Koch, D.-A., 1999, 'Schriftauslegung II', TRE 30(2-3), 457-471.

Kosmala, H., 1959, Hebräer - Essener - Christen. Studien zur Vorgeschichte der frühchristlichen Verkündigung (StPB 1), Brill, Leiden.

Kraus, H.-J., 1978, Psalmen 60-150 (BKAT XV/2), Neukirchener Verlag, NeukirchenVluyn.

Lichtenberger, H. \& Schreiner, S., 1996, 'Der neue Bund in jüdischer Überlieferung', Theologischer Quartalschrift 176, 272-290.

Lundbom, J.R., 1992, 'New Covenant', in D.N. Freedman (ed.), Anchor Bible dictionary, vol. IV, pp. 1088-1094, Doubleday, New York.

Maier, J., 1996, Die Qumran-Essener: Die Texte vom Toten Meer, Bd. III (UTB 1916), Reinhardt, München.

McLay, R.T., 2003, The use of the Septuagint in New Testament research, Eerdmans, Grand Rapids, MI.

McLay, R.T., 2006, 'Biblical texts and the scriptures for the New Testament church', in S.E. Porter (ed.), Hearing the Old Testament in the New Testament, pp. 38-58, Eerdmans, Grand Rapids, MI.

McLean, B.H., 1992, Citations and allusions to Jewish scripture in early Christian and Jewish writings through 180 C.E., The Edwin Mellen Press, Lewiston, ME.

Metzger, B.M., 1951, 'The formulas introducing quotations of scripture in the NT and the Mishnah', JBL 70, 297-307.

Milik, J.T., 1959, 'Notes d'epigraphie et de topographie palestiniennes', Revue Biblique $66,550-575$.

Milik, J.T., 1972, 'Milkî-sedeq et Milkî-rešac dans les ancients écrits juifs et chrétiens', JJS 23, 95-144. http://dx.doi.org/10.18647/614/JJS-1972

Pixner, B., 1992, 'The Jerusalem Essenes, Barnabas and the letter to the Hebrews', in Z.J. Kapera (ed.), Intertestamental essays in honour of Josef Tadeusz Milik, pp. 167-178, Krakow, Jerusalem.

Riggenbach, E., 1922, Der Brief an die Hebräer (KNT 14), Deichert, Leipzig.

Rüsen-Weinhold, U., 2004, Der Septuagintapsalter im Neuen Testament. Eine textgeschichtliche Untersuchung, Neukirchener Verlag, Neukirchen.

Russell, D.S., 1987, The Old Testament Pseudepigrapha, Fortress Press, Philadelphia PA.

Schröger, F., 1968, Der Verfasser des Hebräerbriefes als Schriftausleger (Biblische Untersuchungen 4), Verlag Friedrich Pustet, Regensburg.

Shenkel, J.D., 1968, Chronology and Recensional development in the Greek text of kings (Harvard Semitic Monographs 1), pp. 5-21, Harvard University Press, Cambridge, MA.

Silva, M., 1993, 'Old Testament in Paul', in G.F. Hawthorne, R.P. Martin \& D.G. Reid (eds.), Dictionary of Paul and his letters, pp. 630-642, InterVarsity Press, Downers Grove, IL.

Skehan, P.W., 1964, 'A Psalm manuscript from Qumran (4QPs $\left.{ }^{b}\right)^{\prime}, C B Q$ 26, 313-322.

Soderlund, S., 1985, The Greek text of Jeremiah. A revised hypothesis (JSOT Supp Ser 47), JSOT Press, Sheffield.

Spicq, C., 1952, L'Épître aux Hébreux. I. (Etudes Bibliques), Gabalda, Paris.

Steudel, A., 1994, Der Midrasch zur Eschatologie aus der Qumrangemeinde (4QMidrEschat ${ }^{\mathrm{a}, \mathrm{b}}$ ), Brill, Leiden.

Steyn, G.J., 2000, 'A quest for the Vorlage of the song of Moses (Dt 32) quotations in Hebrews', Neotestamentica 34(2), 263-272.

Steyn, G.J., 2003a, 'Some observations about the Vorlage of Ps 8,5-7 in Heb 2,6-8', Verbum et Ecclesia 24(2), 493-514. http://dx.doi.org/10.4102/ve.v24i2.334

Steyn, G.J., 2003b, 'Psalm 2 in Hebrews', Neotestamentica 37(2), 262-282. 
Steyn, G.J., 2003c, 'Addressing an angelomorphic christological myth in Hebrews?', HTS 59(4), 1107-1128. http://dx.doi.org/10.4102/hts.v59i4.688

Steyn, G.J., 2004, 'The Vorlage of Ps 45:6-7(44:7-8) in Heb 1:8-9', HTS 60(3), 1085-1103.

Steyn, G.J., 2008, 'An overview of the extent and diversity of methods utilised by the author of Hebrews when using the Old Testament', Neotestamentica 42(2), 327-352.

Steyn, G.J., 2011a, 'The Eschatology of Hebrews as understood within a cultic setting', in J. Frey \& J.G. Van der Watt (eds.), Eschatology in the New Testament (WUNT), pp. 429-450, Mohr Siebeck, Tübingen.

Steyn, G.J., 2011b, A quest for the assumed LXX Vorlage of the explicit quotations in Hebrews (FRLANT 235), Vandenhoeck \& Ruprecht, Göttingen.

Stipp, H.-J., 1994, Das masoretische und alexandrinische Sondergut des Jeremiabuches. Textgeschichtlicher Rang, Eigenarten, Triebkräfte, Orbis Biblicus et Orientalis 136, Textgeschichtlicher Rang, Eigenarten,
Vandenhoeck \& Ruprecht, Göttingen.

Terry, M.S., 1975, Biblical Hermeneutics. A Treatise on the Interpretation of the Old and New Testaments, Eerdmans, Grand Rapids, MI.

Thomas, K.J., 1964/1965, 'The Old Testament citations in Hebrews', NTS 11, 303-325. Thompson, J.A., 1989, The book of Jeremiah (NICOT), Eerdmans, Grand Rapids, MI.

Tov, E., 1992, 'The contribution of the Qumran Scrolls to the understanding of the LXX', in G.J. Brooke \& B. Lindars (eds.), Septuagint, Scrolls and Cognate Writings. Papers Presented to the International Symposium on the Septuagint and Its Relations to the Dead Sea Scrolls and Other Writings (Manchester, 1990) (SBLSCS 33) pp. 11-47, Scholars Press, Atlanta, GA.

Ulrich, E.C., 1992, 'The Septuagint manuscripts from Qumran: A reappraisal of their value', in G.J. Brooke \& B. Lindars (eds.), Septuagint, Scrolls and Cognate Writings. value, in G.J. Brooke $\&$ B. Lindars (eds.), Septuagint, Scrolls and Cognate Writings.
Papers Prested to the International Symposium on the Septuagint and Its
Relations to the Dead Sea Scrolls and Other Writings (Manchester, 1990) (SBLSCS 33), pp. 49-80, Scholars Press, Atlanta, GA.

Van der Kooij, A., 1989, 'The Septuagint of Isaiah: Translation and interpretation', in J. Vermeylen (ed.), The book of Isaiah, Le Livre d'Isaïe (BETL 81), pp. 127-33, Peeters Press, Leuven.

Van der Kooij, A., 1989/1990, '1QIsa ${ }^{a}$ Col. VIII, 4-11 (Isa 8,11-18): A contextual approach of its variants', RevQ 14, 569-581.

Van der Kooij, A., 1992, 'The Old greek of Isaiah in relation to the Qumran texts of Isaiah: Some general comments', in G.J. Brooke \& B. Lindars (eds.), Septuagint, Scrolls and Cognate Writings. Papers presented to the International Symposium on the Septuagint and its Relations to the Dead Sea Scrolls and Other Writings (Manchester 1990) (SBLSCS 33), pp. 195-213, Scholars Press, Atlanta, GA.

Van der Kooij, A., 1997, 'Zur Theologie des Jesajabuches in der Septuaginta', in H.G. Reventlow (hrsg.), Theologische Probleme der Septuaginta und der hellenistischen Hermeneutik, pp. 9-25, Gütersloher Verlagshaus, Gütersloh.

Vermes, G., 1977, The Dead Sea Scrolls: Qumran in perspective, Collins, London.

Washburn, D.L., 2002, A catalog of Biblical passages in the Dead Sea Scrolls, TextCritical Studies 2, SBL, Atlanta, GA.

Weiser, A., 1982, The Psalms: A commentary (OTL), SCM Press, London.

Weiss, H.-F., 1991, Der Brief an die Hebräer (KEK 13), Vandenhoeck \& Ruprecht, Göttingen.

Werner, E., 1959, The Sacred Bridge, Dobson, London.

Wilcox, M., 1988, “'According to the pattern (TBNYT)...": Exodus 25,40 in the New Testament and early Jewish thought', RevQ 13(49-52), 647-656.

Yadin, Y., 1959, 'A Midrash on 2 Sam. vii and Ps. i-ii (4QFlorilegium)', Israel Exploration Journal 9, 95-98. 